\title{
5 \\ RE-POSITING GENDER IN THE NEW NATIONALIST PARADIGM
}

\author{
Dinoo Anna Mathew
}

India in recent times has witnessed an expanding role of the national (union) government, with the dominant discourse revolving around military might, national security and a redefining of nationalism, the latter tilting heavily on majoritarianism as a plank for current political engagement and mileage. The increasing focus of the nation's development paradigm is centred on the concepts of 'oneness', 'one nation, one tax', 'one nation, one election' that are mooted by the national ruling party - the Bharatiya Janata Party (BJP). Nationalism and national security are major platforms on which the nation's progress and development are being charted. However these grand nationalist sentiments with a narrow ethnocentric focus obscure the everyday insecurities of local life and the chapter seeks to explain how. Three sets of issues viewed in the context of the current autocratization trends are especially highlighted here. The first relates to the narrow conception of security that has little worth for the rights and security of women and men especially among the marginalized groups. Their security as that of others is intertwined with their daily aspects of life and location in a particular caste, class or gender. The second relates to the various ways in which the space for autonomous functioning of local governments are shrinking due to the increasing centralizing trends by the union government and has the potential to hamper or even roll back the gender equality ideals envisaged and the gains on gender made through political decentralization. The third relates to how the insecurities and fault lines that already existed were magnified in the course of the pandemic.

\section{Obscuring the local}

The political vocabulary and its outreach in the past few years in the country have been dominated by the conceptions of military might, nationalism and national security, the core elements of the 2019 election manifesto of the BJP that sought to attract the electorate. This articulation of nationalism and the dominant narrative of safeguarding the nation from inimical neighbours found deep resonance with the voters in the past two elections to the lower house of parliament. However the question that looms large is: can the contours of national security that is advocated be divested of the core security concerns and wellbeing of its citizens? 
The realist notion of security that is predominantly state centric has long been challenged by critical-security and feminist security studies (Steans 1998: 126, Tickner 2001: 43). Criticalsecurity studies in broadening the conception of security from a traditional state centric and sovereignty analysis, have argued that security needs to be viewed from a bottom-up perspective, focusing on the individual with the goal of emancipation that frees people from social, physical, economic, and political constraints that restrain their free choice of doing what they want to do (Tickner 2001: 47). Deepening the debate, feminist security studies have overwhelmingly stressed the reassessment of notions of security to move beyond its traditional notions that privilege territorial integrity to viewing the manifold sources of insecurity that are immediate threats to women and specific groups according to their particular situations (Steans 1998: 126). Along with ecological concerns, feminist security studies therefore point out the insecurities posed to individuals and groups, especially women, by physical and structural violence (Terriff et al. 1999: 87). A broader understanding of security from a feminist perspective therefore entails locating women in their immediate environment, understanding the violations of their security while also assessing this from the standpoint of a patriarchal framework that promotes and sustains this violence (ibid. 86).

Viewed from this perspective, the insecurities faced by women in India are many and varied. Women continue to live in a society marked by patriarchal norms and attitudes and where there is a clear public-private distinction. According to the data from the National Crime Records Bureau, crimes against women have been steadily increasing over the years, with domestic violence against women the highest among them. This phenomenon of domestic violence which originates from and reifies the patriarchal norms in society denies women their fundamental security from violence. There is alarmingly high unemployment and abysmally low engagement of women in the labour market in India. The Economic Survey of India for the period 2019 to 2020 pointed out a decline in female labour force participation among the productive age group of 15 to 59 years, from 33.1 per cent in 2011 to 2012 to 25.3 per cent in 2017 to 2018, with a sharper decline evident in rural areas. The female worker population ratio also declined from 32.3 per cent in 2011 to 2012 to 23.8 per cent in 2017 to 2018 among the productive age groups. Unpaid domestic responsibilities and care work are disproportionately skewed towards women in India. In the last two decades there is an increasing proportion of working age women attending only to domestic duties and which in 2017 to 2018 was around 60 per cent (Economic Survey 2019 to 2020: 290). This is to a very large extent shaped by the prevailing social norms and unequal gender hierarchies that identify women's work with domestic responsibilities and care work and relegate them to a secondary status in the labour market. The devaluation of their contribution is compounded where their labour contribution is rendered invisible by viewing it as an extension of their domestic responsibilities or attributing to the essentialist notions of women's 'natural' care giving instincts. The critical aspects of their rights in terms of adequate wages and social protection are then not given their due importance. The agriculture sector, for instance, continues to be the main sector where women are employed, the nature of work is highly informal and women form the highest group of landless labourers (Chakraborty 2020: 289-290). It was only recently that women in the agricultural sector were recognized as farmers both by farmers' collectives and the state. With the decline in the agricultural sector, there has been an increased migration of men from rural to urban areas in search of work contributing to the high presence of femaleheaded households and feminization of agriculture. With limited access to land rights, to technical inputs and assets, and with restricted mobility, the challenges to women are many in such situations. Another instance is of community health workers known as accredited social health activists, mostly women, who are outside the ambit of any kind of livelihood security. 
The same social and patriarchal norms extend to other arenas that depict women as needing to be controlled and incapable of making decisions on their own account. Some of these issues have been carried over from the past decades. Yet not only are these challenges progressively rising, currently there are disturbing trends that reflect a deepening of these concerns. Coupled with the interplay of caste and religion, an obvious manifestation of this phenomenon is the increasing incidence of honour killings and the calls to 'save' Hindu women from Muslim men through interfaith marriage or what the radical Hindu groups speciously call 'love jihad'. While some states in India already had legislation on freedom of religion, what is new is the increasing rhetoric around interfaith marriages with an overarching impulse to dictate women's choice regarding marriage, portraying them as defenceless and devoid of agency. To provide legal sanction, various states, especially those ruled by the ruling party at the national level, are rushing to bring in legislation regulating interfaith marriages focusing solely on religious grounds to decide the legality to the marriage. Other instances include the recent nonviolent protests, one led by women and formed against the backdrop of the amendments brought by the national government to the Citizenship Act. The other is the women farmers being one with their male counterparts protesting against the newly introduced farm laws by the national government. Both these agitations attracted participants across class, castes, and religious groups, lending a multihued articulation of their rights and insecurities. Despite the protracted nature of these protests, however, the state was and is found wanting in acknowledging and addressing their concerns and insecurities.

Since 1996 there have been multifaceted efforts by various governments to successfully pass the women's reservation bill providing for one third of the total number of seats in the lower house of parliament (Lok Sabha) for women. To date, the status quo on the women's reservation bill continues, even though its promise makes its way into political party manifestos, including that of the current political party. With the increasing impact of climate change and natural disasters, women suffer disproportionately through displacement, loss of livelihoods, lack of food, and gender-based violence. These environmental security issues and socio-structural security concerns of gendered violence, limited political and cultural autonomy, sexual division of labour, and increasing unemployment faced in their everyday lives are far more detrimental to women. Most of these gender insecurity concerns relate to the core issue of the sustainable development goal five: freedom from all forms of violence and discrimination and the promotion of gender equality and women's empowerment. Hence, where women continually face insecurities arising from direct gender-based violence, socio-structural violence and environment concerns among others, and where this does not come into the rhetoric of security that is being advanced, then the latter seeks to address only a partial notion of security. This narrow perspective of security that is foisted on citizens divests itself of addressing the lived realities of women and marginalized groups, the lived realities that matter to them most and shape their experience and idea of security.

\section{Shrinking space of local governments}

With the increasing linkages of global and local challenges of rapid urbanization, climate change, migration, displacement, growing inequalities and the drive against gender equality, various international bodies have been calling for a multi-level governance approach to address these issues. The United Nations, in setting the roadmap for the localization of sustainable development goals for instance, has underscored the significance of local governments as important partners in its achievement through promoting inclusion, diversity, and broad-based ownership (Global Taskforce of Local and Regional Governments 2016: 7). Further it calls for an approach 
for bringing together various government levels and different stakeholders to lead to a transformative change at the local level. Other organizations and networks, such as the United Cities for Local Government and the Global Parliament of Mayors, have been advocating the importance of cities engaging with global challenges and for multi-level governance frameworks that are inclusive. There is thus an increasing recognition of localization and local governments to design local actions involving local stakeholders and in ensuring the voice and decisions of women and marginalized groups to address global challenges.

Local governments, because of their proximity to people and the relevance of local services to their constituents, have the potential to advance women's participation and representation in their decision-making processes. Internationally local and regional governments have been calling attention to the imperativeness of increased participation of women in local governments. The worldwide declaration on women in local government by the International Union of Local Authorities in 1998, which has since inspired many other calls for gender equality, stated: "Local government is an integral part of the national structures of governance and the level of government closest to the citizens. Therefore it is in the best position both to involve women in the making of decisions concerning their living conditions and to make use of their knowledge and capabilities in the promotion of sustainable development" (IULA 1998). Other significant initiatives included the European Charter for Equality of Women and Men in Local Life (2006), and the Paris Local and Regional Global Government Agenda for Equality of Women and Men in Local Life.

In India, given its size, vast population and the diversity of states that are held together in the federation, multi-level governance frameworks and localization assume even greater significance. However, it has been argued that while India adopted a federal structure, it conforms more to a 'quasi federal' structure and embodies both federal principles as well as strong centralizing features (Singh N. 2016: 522, Singh M. 2016: 464). Autocratizing trends can therefore pose a clear and present danger. With regard to the legal constitution of local governments, even during the framing of the Indian Constitution, there were almost equal debates for and against inclusion of local governments as basic units of government with financial powers. Ultimately as a compromise formula, the provision for local governments was included in the Indian Constitution, under the Directive Principles of State Policy, which are non-enforceable recommendations for the governance of India (Sivaramakrishnan 2016: 562). It took another four decades for the passage of the 73rd and 74th constitutional amendment acts in 1992, mandating the creation of rural and urban local self-governments respectively. The responsibility of devolving powers and responsibilities to local self-governments were left to the individual states of India. Hence the progress of decentralization varied across states, with many states making huge progress and others lagging behind. At the union government level, in the early 2000 s there were systematic efforts towards facilitating the transfer of functions and functionaries by states to local governments through activity mapping (a process by which functions of local governments are delineated into activities and sub-activities to enable functional clarity for service delivery outcomes). Many states, in fact, progressed well in terms of activity mapping, yet the momentum kept varying.

The political decentralization process through the seventy-third and seventy-fourth constitutional amendment acts was a democratic mechanism that not only provided legal space for women's political leadership, but also a platform where the voices of women and men at the local level could be asserted, where they could stake a claim to democracy, and where the intersections of gender, caste, and class play out in the day-to-day lived realities. The acts provided 33 per cent reservation to women and proportional representation to scheduled castes and scheduled tribes in the rural and urban local governments. Various state governments 
moved further and provided 50 per cent reservation to women in local governments. This assumes enormous importance given that the proportion of women fielded as candidates for the lower house of parliament and the state legislative assemblies by political parties has been very low. However, at present there are discernible centralizing trends by the union government, leading to an incremental encroachment of the functional and financial space of the local governments. These put at risk the inclusive and equity issues sought to be addressed through the involvement of local governments.

The greatest trends are seen in the fiscal realm of local governments. It is evident that the presence of optimum amounts of funds at the discretion of the local government council is imperative to plan for locally relevant needs and priorities. In India, the revenue collected in the form of taxes and fees is a vital source for local governments with regard to funds at their disposal. However, this revenue has been declining over the years. Further, with the introduction of the goods and services taxes (GST) by the union government in 2017, the local governments in particular lost out on some of their rights of taxation especially with regard to entry tax, octroi, local body tax, and advertisement tax, which were a significant source of revenue. In the present arrangement, the proceeds from GST are divided only between the union and the states (ICRIER 2019: 6). The local government does not receive any proceeds even though three major taxes that they enjoyed earlier were absorbed into the GST. The other source of major revenue for local governments in India is the union finance commission grants. The recent Fifteenth Finance Commission has recommended rupees 90,000 crore as total grants for local governments for the 28 states for the period 2020 to 2021 . However, out of this, 50 per cent of the funds for rural local bodies and for fifth and sixth schedule areas are tied in nature, meaning that they can be used only for the basic services of (a) sanitation and maintenance of open defecation-free status and (b) supply of drinking water, rainwater harvesting and water recycling (Fifteenth Finance Commission 2019: 49). Similarly for urban local bodies other than million-plus cities (cities with a population of one million or above), 50 per cent of the allocation is tied to drinking water (including rainwater harvesting and recycling) and solid-waste management. For the million-plus cities grants are allocated for the purpose of improving ambient air quality and for improving conservation, supply and management of water and efficient solid-waste management. With only 50 per cent of the allocation unconditional in nature, the local governments will have restricted funds at their disposal for planning efficiently for projects for their felt community needs.

The previous Fourteenth Finance Commission had specified 90 per cent and 80 per cent of its recommended allocation for rural and urban local governments respectively to be in the nature of basic grant and the remaining 10 per cent and 20 per cent as performance basic grants for rural and urban local governments respectively. The rationale was to provide unconditional support in the form of basic grants to the village panchayats and municipalities to improve the basic civic services including water supply, sanitation including septage management, sewerage and solid-waste management, storm water drainage, maintenance of community assets, maintenance of roads, footpaths and street lighting, and burial and cremation grounds (Fourteenth Finance Commission 2017: 123). To be eligible for performance grants, the Finance Commission laid the conditionality for local governments to submit audited annual accounts and to show an increase in own revenues over the preceding year. The commission also recommended that the union government accept their guidelines without imposing any further conditions. This, however, did not happen as pointed out by a study commissioned by the Fifteenth Finance Commission. The study highlighted that though the recommendations were accepted by the union government, in the course of time, further conditionalities were imposed by union ministries that sought to restrict the autonomy of local governments to spend the funds and by 
ascribing them to spend the resources on specific sectors determined by the union government (Accountability Initiative 2019: 17).

In other words, the union government brings out policies that require certain conditionalities which put the local governments at loggerheads with the conditions of the finance commission and that of the union government. This, coupled with the overall trend of low absorptive capacity of local governments that are unable to efficiently expend financial resources matching the needs or the priorities in their local development plans, leads to the situation where they are left in disarray. Low technical capacities and skills of local governments at financial and administrative levels has been a perennial problem which has not been given due and sustained importance. This impedes local innovation to address issues and challenges and to evolve alternative solutions.

Village panchayats are a microcosm of society in India. If viewed in that sense it is a platform where human interactions and frictions play out. Issues that have a direct impact on women (their freedom, independence, and safety) have a larger import in the local arena especially forums that are at the local level. Here the local councils are the immediate point of reference to articulate their issues. Where discretionary funds are limited, the scope for planning for women-specific needs and priorities diminishes. Issues of marital disputes, alcoholism, dowry, domestic violence, violence against women, gender impacts of declining agriculture, and rising unemployment among women then get lost or side-lined.

It was in 2005 to 2006 that a significant step towards including a gender budgeting statement in the Union budget was introduced. It was envisaged at that time that "the budget data will in due course be presented in a manner that the gender sensitivities of the budgetary allocations are clearly highlighted" (Gender Budgeting 2005 to 2006: 50). The budget statement has two parts which indicate budget provisions for schemes for the benefit of women: part A details schemes in which 100 per cent provision is for women and part B details schemes where 30 per cent provision has been earmarked for women. According to the gender budget statement of 2016 to 2017, "the purpose of gender budgeting is to monitor expenditure and public service delivery from a gender perspective, as a means of mainstreaming women's concerns in all activities and improving their access to public resources" (Ministry of Finance 2016 to 2017: 97). In examining the gender budget statements from 2005 to 2006 and 2020 to 2021, it is seen that the Ministry of Panchayati Raj (ministry responsible for rural local governments) furnished allocations under part B from 2008 to 2009 onwards until only 2016 to 2017. Thereafter there has been no reporting of allocation. The Ministry of Housing and Urban Poverty Alleviation has furnished allocations from 2006 to 2007 until 2016 to 2017 under part B, after which there has been an allocation only in 2020 to 2021 by the Ministry of Housing and Urban Affairs.

Another major centralizing trend is seen in the centralized provision of local services bypassing the functional and financial mandate of the local governments. As early as in 1993 the then Congress government had introduced a local area development scheme for members of parliament called the MPLADS. The scheme started with an annual allotment of one crore Indian rupees to each member of parliament to implement small works in his/her constituency. This was against the spirit of decentralization and federalism as the funds that were given to the members of parliament were actually funds that could have been at the disposal of the local governments. Further, by spending on local area development in their constituency, they were encroaching on the functional space of local governments who were and are still grappling with the ambiguities and overlap of their functions. The annual allotment was later increased to five crores of Indian rupees. Following this scheme various states' governments also initiated the local area development scheme for members of state legislative assemblies. The centrally sponsored schemes funded by the Union government with a matching grant from the state governments and which 
are tied to specific projects are yet another example of how national priorities get privileged over local needs and priorities. Over the years the scope of centrally sponsored schemes has been steadily increasing resulting in local governments being pressurized by imposed conditionalities, and a one-size-fits-all approach that goes against the grain of the 73rd and 74th constitutional amendment acts. The present BJP government had started yet another similar programme in 2014 called the Saansad Adarsh Gram Yojana (model village). It delegated responsibility to each member of parliament to adopt one village panchayat of his or her constituency and develop it into a model village by 2016, followed by two more village panchayats by 2019 and five more village panchayats by 2024. According to the performance review committee meeting of the Saansad Adarsh Gram Yojana in November 2017, 14 union ministries amended the guidelines or issued advisories with respect to 21 central schemes to enable priority for those panchayats that were identified under Saansad Adarsh Gram Yojana (Saansad Adarsh Gram Yojana 2017). All this points to how centralizing trends are autocratizing the spaces of local governments to function as de facto independent third tiers of government in the country.

There is enough evidence that argues for women to have an enabling environment in their homes so as to effectively exercise their responsibilities as locally elected members. However, critical aspects that still hamper women's prospects in political decentralization are the social norms and patriarchal environment in which women elected members have to function. Society continues to have deep-seated male-dominated attitudes that subordinate women. Data from the National Crime Records Bureau point to the increasing cases of crimes against women over the years. In 2019, the latest year for which data is available, there has been an increase of 7.3 per cent in cases of crimes against women (Crime in India 2019: xii). Evidently, it is domestic violence (cruelty by the husband or his relatives) that constitutes the majority of the cases registered under crimes against women.

Given the male-dominated political sphere, it is not surprising therefore that political representation of women in the parliament and state legislative assemblies has been very low. Political parties have for long restricted the number of women contestants to both the lower house of parliament and the state legislative assemblies. In fact, the percentage of women candidates contesting elections to the lower house of parliament was just 7 per cent in the period 2002 to 2019, some 4 per cent in 1977 to 2002 and 3 per cent in 1952 to 1977, even though women's winning strike rate is greater than men's (Roy and Sopariwala 2019: 242).

It is not that women are far removed from politics or are disinterested in the governance of the country. This is illustrated by the large numbers of women voters for all elections, which is highest for local government and state legislative assembly elections, followed by elections to the lower house of parliament. In fact, according to Roy and Sopariwala the greater turnout of voters, especially women in rural areas, has had an impact on the electoral strategies of major political parties (ibid. 49).

While arguing that the infringement of the financial and functional spaces of local governments is part of the current autocratization trends, this chapter also acknowledges the fact that just as other levels of governments, local governments too have their own challenges. However, this entails a separate discussion. Nonetheless, suffice to say that it cannot be assumed that local governments will be devoid of binding constraints and forces that negate the interests and rights of women and marginalized groups. What is required is for the national government and the states to provide the importance due to local governments as the primary sphere for local citizen engagement, a critical platform for realizing local aspirations and currently the only tier of government where mandated reservation is provided for women and marginalized groups. Local governments need to be nurtured and provided an enabling environment for 
them to work towards their potential of providing inclusive and accountable governance. It is true that local governments come under the ambit of the respective state governments and the latter in many states have shown reluctance to devolve functions and finances to local governments. However, the union government cannot shirk its responsibility towards enabling local governments to evolve as a self-governing third tier of the government in the federal structure. To date there have been no efforts by the present union government towards incentivizing state governments to devolve powers to local governments. On the other hand as the above discussion shows, there has been an incremental encroachment into the space of the local governments.

\section{The Covid-19 pandemic}

Societies are prone to shocks, both from within and those that are extraneous which are beyond their control. It is when they face these endogenous or exogenous shocks that they are really tested. The risks and vulnerabilities of women and marginalized groups are amplified during these times, especially where adequate attention and institutional measures to address these risks and vulnerabilities were minimal during 'normal' times. The pandemic took the form of such an extraneous shock that challenged and out-manoeuvred governments as the former ramped up its destructive scope. In India, the onset of the Covid-19 pandemic laid bare the lack of security and social protection for women and various social groups. Whereas such insecurities were rendered invisible during 'normal times' in the dominant narrative and discourses, it was only natural that they were exacerbated during the pandemic. The institutional measures to address these insecurities were severely lacking in their time-bound and sustained interventions. In April 2020 the United Nations Secretary-General called urgent attention to a "horrifying global surge in domestic violence" directed towards women and girls during the lockdown and importantly pointed out that violence is not just in the battlefield but "for many women and girls, the threat looms largest where they should be safest: in their homes" (United Nations 2020). In India, according to the National Commission for Women, there was an increased surge in the incidence of domestic violence. The Centre for Monitoring Indian Economy, a leading business information company and an independent think tank, had highlighted that women had a pronounced unequal share of job losses (13.9 per cent) as early as April 2020 and by November 2020 compared to men, a higher proportion of women were unable to re-enter the job market (Vyas 2020). Due to the prevailing gender inequalities and norms, girls are more likely to drop out of school than boys, severely affecting their educational and life outcomes. The pandemic has worsened the situation pushing them back reluctantly into domestic and informal jobs. The pandemic further exposed the weak and infrequent focus by the government on basic health care, especially primary health centres, impacting further the critical health care needs, especially of women in rural areas.

The above discussion reinforces the need for localized interventions that focus on better outcomes where factors of efficiency and equity are adequately addressed. The need for a sustained and enabling environment for local governments to be active and responsive in addressing these challenges cannot be overstated. However, during the pandemic, local governments were not considered as critical layers of government in responding to the overwhelming challenges thrown by the pandemic, challenges that at the same time were localized in nature and required localized approaches.

In response to the pandemic, the union government invoked the Disaster Management Act of 2005. While the act details the responsibilities of the union and state government, there is only a limited mention of the local governments. In India the lockdown came into force on 25 
March 2020 and was lifted through varying phases by end of May 2020. For the implementation of the disaster management plan, local governments are the appropriate level of government, but they were never in the picture. In the initial stages as the lockdown eased, it was only the union government taking decisions. Later, the state governments were given directions within the overall framework set by the union government. The urban local governments came in last with the only exception being the Mumbai municipal corporation which took the responsibility for the Dharavi slum and to a large extent prevented the spread of the virus. Barring few state governments, like Kerala and Odisha that empowered local governments to work alongside them in addressing the pandemic, in many others there were hardly any formal powers that they enjoyed.

\section{Conclusion}

In India, since the overwhelming return of the BJP to power in the 2019 general elections, increasing trends towards undermining the power of states and a domineering stance of the centre has cast its shadow on the federal structure of the country. Politically this tension is manifest in the ways that the national government seeks to address issues without adequate deliberations and discussions. A recent case in point is the unilateral decision on critical farm law bills in parliament without reasonable discussion. Further, constraining the fiscal ability of states to spend on key priority areas, the national government's increasingly parochial attitude is steering the states into a bind.

The significance of multi-level governance and localized approaches to meet the diverse challenges facing the countries of the world cannot be emphasized enough. There is a need to realign priorities that take into account the lived realities of citizens especially those who are left behind in the overall growth and development of political discourse and practice. As the above discussion points out, this is particularly relevant for India, in a context where there has been a faltering of federal principles, a gradual concentration of powers and functions and its impact on issues relating to equality. The invisibility of the local and lived realities of people in security discourses resurfaces with the slow de-legitimization of the local governments, democratic institutions that are closest to the people. What is paramount is the urgent need to converse with people, especially women, the marginalized, the minorities, and those who feel left behind, building bridges with them and being responsive to their needs and securities; at the same time enriching and nourishing core democratic institutions such as the local governments that are invariably the first line of government that common citizens have access to. A divergent move that tends to centralize powers and functions fails to resonate with the needs of common citizens leaving them to deal with the insignificance of political rhetoric. This runs the risk of situations emerging that are more autocratic in nature sidestepping the essence of a democratic process. As is argued, for the 'real majority', that is, the poor, women, minorities, and marginalized groups, a negation of democracy and their rights is then a reality that they reluctantly have to live with.

\section{Glossary}

basic grant: untied grant that may be used for core development activities of local governments

crore: ten million

Dharavi: $\quad$ one of Asia's largest slums and located in the Indian state of Maharashtra 
fifth schedule area:

Lok Sabha:

panchayat:

performance grant:

Saansad Adarsh Gram Yojana: scheduled castes:

scheduled tribes:

sixth schedule area: constitutionally designated tribal majority area in certain states of India

lower house of parliament

village council

a targeted grant made based on specific goals achieved during a specified period

model villages

historically underprivileged groups of people recognized in the constitution of India

tribes or tribal communities recognized in the constitution of India

constitutionally designated tribal area in the north-eastern states of India

\section{Bibliography}

Accountability Initiative, Centre for Policy Research (2019) Devolution of Union Finance Commission Grants to Panchayats. A Study for the Fifteenth Finance Commission. Finance Commission, India (fincomindia.nic. in) (Accessed 16 October 2020).

Chakraborty, Shiney (2020) 'Covid-19 and Women Informal Sector Workers in India', Economic and Political Weekly, 55(35), pp. 17-31

Council of European Municipalities and Regions (2006) European Charter for Equality of Women and Men in Local Life. www.charte_egalite_en.pdf (ccre.org) (Accessed 24 September 2020).

Government of India, Saansad Adarsh Gram Yojana. https://rural.nic.in/sites/default/files/SAGY_PRC_ 17Nov2017.pdf (Accessed 13 October 2020).

Government of India Disaster Management Act (2005) The Disaster Management Act, 2005.pdf (mha. gov.in) (Accessed 6 October 2020).

Government of India Ministry of Finance (2017) Fourteenth Finance Commission. New Delhi.

Government of India Ministry of Finance (2019) Fifteenth Finance Commission. New Delhi.

Government of India Ministry of Finance (2019-2020) Economic Survey. New Delhi.

Government of India Ministry of Finance (2005-2006 and 2020-2021) Gender Budgeting. New Delhi.

Government of India Ministry of Home Affairs (2019) Crime in India. New Delhi.

Global Taskforce of Local and Regional Governments. Roadmap for Localizing the SDGs: Implementation and Monitoring at Sub-National Levels. 818_11195_commitment_ROADMAP LOCALIZING SDGS. pdf (un.org). (Accessed 26 July 2020).

Indian Council for Research on International Economic Relations (2019) Finances of Municipal Corporations in Metropolitan Cities of India. A Study for the Fifteenth Finance Commission: Finance Commission, India (fincomindia.nic.in) (Accessed 16 October 2020).

International Union of Local Authorities (1998) Worldwide Declaration on Women in Local Government. Rat der Gemeinden und Regionen Europas: IULA Worldwide Declaration on Women in Local Governments (mittwaldserver.info) (Accessed 21 September 2020).

Roy, Prannoy and Dorab R. Sopariwala (2019) The Verdict Decoding India's Elections. India: Penguin Random House.

Seans, J. (1998) 'Feminist Perspectives on Security', in Gender and International Relations: An Introduction. New Brunswick, NJ: Rutgers University Press.

Singh, Mahendra Pal (2016) 'The Federal Scheme', in (eds.), Sujit Choudhry, Madhav Khosla, Pratap Bhanu Mehta, The Oxford Handbook of The Indian Constitution. New Delhi: Oxford University Press.

Singh, Nirvikar (2016) 'Fiscal Federalism,' in (eds.), Sujit Choudhry, Madhav Khosla, Pratap Bhanu Mehta, The Oxford Handbook of The Indian Constitution. New Delhi: Oxford University Press.

Sivaramakrishnan, K.C. (2016) 'Local Government,' in (eds.), Sujit Choudhry, Madhav Khosla, Pratap Bhanu Mehta, The Oxford Handbook of The Indian Constitution. New Delhi: Oxford University Press.

Terriff, Terry, Stuart Croft, Lucy James, and Patrick M. Morgan (1999) 'The Impact of Gender on Security,' in Security Studies Today. Cambridge: Polity Press. 
Tickner, J.A. (2001) Gendering World Politics. New York: Columbia University Press.

United Nations (2020) Amid Global Surge in Domestic Violence, Secretary General Urges Governments to Make Prevention, Redress Part of National Covid-19 Response Plans, Meetings Coverage and Press Releases (un. org) (Accessed 28 October 2020).

Vyas, Mahesh (2020) Female Workforce Shrinks in Economic Shocks, Unemployment (cmie.com) (Accessed 18 December 2020). 